\title{
Effects of Human Papillomavirus Infection with Pre- invasive Cervical Lesions: Bangladesh Perspectives
}

\author{
MITA JOARDER ${ }^{1}$, SHIRIN AKTER BEGUM², MD. RASEL AHMAD³, MD. IMMAM HOSSIN ${ }^{4}$ \\ SHANJIDA ISLAM ${ }^{5}$, MD ABDULLAH AL HARUN ${ }^{6}$
}

\begin{abstract}
:
Background: Cervical cancer remains a major public health problem worldwide - particularly in less developed countries. Around $85 \%$ of their new cases and $86 \%$ of deaths occur in less development countries (IARC, 2012). In Bangladesh, Cervical cancer is the second most common disease among female with an estimated 11,956 new cases and 6,582 deaths in 2012.

Objectives: The present study was undertaken to identify the Effects of Human Papillomavirus infection with Pre-invasive cervical lesions in Bangladesh.

Methods: This cross sectional study was carried out at the colposcopy clinic of Gynaecology and Obstetrics department of Bangabandhu Sheikh Mujib Medical University during the study period January 2015 - December 2015. A total of 65 consecutive women with VIA +ve cases of all three grades of CIN (CIN I, CIN II, CIN III) were enrolled in this study. Women having invasive cervical disease and women who not interested were excluded from this study.

Results: More than one third (35.3\%) patients were in $3^{\text {rd }}$ decade. More than one third (35.4\%) patients had normal colposcopic findings followed by 23(35.4\%) was CIN I, 11(16.9\%) was CIN II and 8(12.3\%) was CIN III. Majority (42.6\%) patients was found CIN I, 11(26.1\%) was CIN II, 8(19.4\%) was CIN III and 5(11.9\%) had normal in Histopathology. CIN I histopathological finding was found 18 cases, among them $8(44.4 \%)$ in positive HC-2Niral load/ RLU index. In multivariate analysis CIN III was significantly increased 1.34 times in HC-2/Viral load/RLU index positive (human Papillomavirus) cases $(95 \% \mathrm{Cl} 0.22-8.9 \%$, $<0.05)$. Validity test of benign HPV DNA test of the study women showed that HPV DNA had sensitivity $51.4 \%$, specificity $92.9 \%$, accuracy $69.2 \%$, positive predictive values $90.5 \%$ and negative predictive values $59.1 \%$. Benign Colposcopic finding had had sensitivity $86.5 \%$, specificity $64.3 \%$, accuracy $76.9 \%$, positive predictive values $76.2 \%$ and negative predictive values $78.3 \%$. CIN III significantly 1.34 times increased HC-2/Viral load/ RLU index positive (human Papillomavirus) in multivariate analysis.

Conclusion: From the findings of the study it was observed that colposcopy had a high sensitivity and optimum specificity; HPV DNA test had lower sensitivity and higher specificity. Colposcopic findings were closely associated with Histopathology, where the validity test was high when compared to HPV DNA test. So it can be concluded that the Colposcopy is a useful screening test for detection of cervical lesions and Human Papillomavirus is associated with pre-invasive cervical lessons. So the HPV DNA test can be used as a co-test with Colposcopy for screening of cervical lesions.
\end{abstract}

Key words: Effects Human Papillomavirus, Infection, Pre-invasive, cervical lesions.

1. Asstt. Professor of Obs. \& Gynae, Dhaka Medical College.

2. Department of Obs and Gynae, Bangabandhu Sheikh Mujib Medical University, Dhaka.

3. Dental surgeon and Medical Educationist, Consultant United Oro-Dental and Maxillofacial surgery.

4. Medical Educationist \& Dental Surgeon, Department of Oral and Maxillofacial Surgery, Dhaka dental College Hospital.

5. Dental surgeon, Consultant United Oro-Dental and Maxillofacial Surgery.

6. Director,(Hospital), Bangabnadhu Sheikh Mujib Medical University.

Address of Correspondence: Dr. Mita Joarder, Asstt. Professor of Obs. \& Gynae, Dhaka Medical College. Cell: 01711395275, E-mail: dr.mitajoarder@gmail.com 


\section{Introduction:}

In Bangladesh, Cervical cancer is the second most common disease among female with an estimated 11,956 new cases and 6,582 deaths in 20121. Hospital based statistics indicated that cervical cancer constitutes $22-35 \%$ of the female cancer in different areas of Bangladesh ${ }^{2}$. Majority of the patients diagnosed with this preventable cancer present in clinically advanced inoperable stages. The literature identifies several risk factors for the acquisition and prevalence of HPV infection. Age is a strong predictor. Other factors include number of recent / life time sexual partners, age at onset of sexual activity, socio-economic status, male circumcision, extended use of condom, oral contraceptive use, cigarette smoking. ${ }^{3-7}$ High parity will also be identified as a risk factor for HR-HPV infection ${ }^{8}$. Human papilloma virus (HPV) is one of the most commonly acquired sexually transmitted infection and significant source of morbidity and mortality ${ }^{9}$. HPV is recognized as estimated cause of cervical cancer and pre-invasive condition for last few decades ${ }^{2}$. Persistent infection with certain types of HPV is a leading cause of cervical cancer. About 10-15 types of high and intermediate risk HPV (HRHPV) types are responsible for more than $90 \%$ of cervical cancer. As persistence of certain risk groups of HRHPV plays very important role in development of cervical cancer and CIN. Identification of prevalence of HPVs among women with $\mathrm{CIN}$ and normal cervix play important role in screening, prevention and management of CIN. The cervical cancer rates in the United States have progressively declined because of the widespread application of cervical cancer screening and treatment of precancerous lesions, but in the low income countries the incidence in still high because of lack of well-organized screening programme. The presentence and severity of precancerous changes influences the progress of the diseases. The likelihood of regression of CIN I, CIN II, CIN III is $60 \%, 40 \%, 33 \%$, respectively and progression to invasive stage is $1 \%, 5 \%$ and greater than $12 \%$ respectively. The time interval between infection and development of cervical cancer varies and is apparently more than 15 year $^{9}$. Apart from the risk factors that are already described, the most important risk factor in low income countries is infrequent cervical screening or lack of accessible cervical screening services. Infections with highrisk strain of Human Papilloma Virus (HPV) are of the root causes of cervical cancer. The virus cancer like works by triggering alterations in the cell of the cervix, which can lead to the development of cervical intraepithelial neoplasia (CIN), which may be turned into invasive cervical cancer (ICC) subsequently.

\section{Methodology:}

This cross-sectional study was conducted in colposcopy clinic of BSMMU during January 2015 to December 2015. For each of every subject separate data collection sheet were prepared. The subjects were 65 women with VIA + ve cases attending the colposcopy clinic of BSMMU. The purpose and procedure of the study were discussed with the patients. Written informed consent was obtained from those who agreed to participate in the study. On receipt of the informed consent, cervical sample was taken with a special cytobrush and transport media used for collection and transport of cervical specimen. The specimens were stored at $-20^{\circ} \mathrm{C}$ upon receipt, until processing. Detection of HPV DNA from cervical samples was performed by hybrid capture 2 (HC-2) tests. HC-2 test was used to examine the existence of HPV DNA in each specimen. Data was collected from the study population on variables of interest using structured design by interview, observation, clinical exam, HPV DNA test, Colposcopic findings and histopathological examination.

Results: Table I shows demographic variable of the study subjects. It was observed that more than one third (35.3\%) patients belonged to age $31-40$ years. The mean age was found $35.5 \pm 9.6$ years with range from 21 to 58 years. Age of marriage was found $17.0 \pm 3.6$ years with range from 12 to 26 years. Majority $(89.2 \%)$ patients were Muslim. Most of the (84.6\%) patients were housewives. Twenty $(30.8 \%)$ patients had completed primary education. More than a half $(54.4 \%)$ of the patients came from 10,000 20,000 taka monthly income family. The mean age at $1^{\text {st }}$ child was found $19.3 \pm 3.7$ years with range from 13 to 29 years. 
Table-I

Distribution of the study population by demography variable $(n=65)$

\begin{tabular}{lcc}
\hline Demography variable & Number of & $\begin{array}{c}\text { Percentage } \\
\text { population }\end{array}$ \\
\hline
\end{tabular}

Age (in years)

21-30

$31-40$

$41-50$

$51-60$

Mean \pm SD

Range (min, max)

Age of marriage

$\leq 18$

$>18$

Mean \pm SD

Range (min, max)

Religion

Islam

Hindu

Occupational status

House wife

Service holder

Other work

Educational status

No education

Primary

Secondary

Higher secondary

Graduate

Monthly income (taka)

10,000-20,000

$21,000-30,000$

$>30,000$

Age at $1^{\text {st }}$ child

$<18$

$18-20$

$>20$

Mean \pm SD

Range (min, max)
21

23

43

22

17.0

58

7

10.8

8

2

17

10.8

30.8

26.2

16.9

15.4

26

17

40.0

22

19.3

32.3

35.3

26.2

6.2

60

66.2

33.8

$\pm 3.6$

, 26

84.6

12.3

3.1

55.4

18.5

26.2

13

Table II shows colposcopic finding of the study population, it were observed that majority $(35.4 \%)$ patients had normal colposcopic findings followed by $23(35.4 \%)$ were $\mathrm{CIN} \mathrm{I}, 11(16.9 \%)$ were CIN II and $8(12.3 \%)$ were CIN III.

Table-II

Distribution of the study population (CIN I by VIA lest) based on colposcopic findings $(n=65)$

\begin{tabular}{lcc}
\hline Colposcopic findings & $\begin{array}{c}\text { Number of } \\
\text { population }\end{array}$ & Percentage \\
\hline Normal & 23 & 35.4 \\
CIN I & 23 & 35.4 \\
CIN II & 11 & 16.9 \\
CIN III & 8 & 12.3 \\
\hline
\end{tabular}

Table III shows histopathological findings among study population, it was observed that $28(43.1 \%)$ women were found colposcopically normal followed by $18(42.6 \%)$ were CIN I, 11(26.1\%) were CIN II and $8(19.4 \%)$ were CIN III.

Table-III

Distribution of the histopathological findings among study population $(n=65)$

\begin{tabular}{lcc}
\hline $\begin{array}{l}\text { Histopathological } \\
\text { findings }\end{array}$ & $\begin{array}{c}\text { Number of } \\
\text { population }\end{array}$ & Percentage \\
\hline Normal & 28 & 43.1 \\
CIN I & 18 & 27.7 \\
CIN II & 11 & 16.9 \\
CIN III & 8 & 12.3 \\
\hline
\end{tabular}

Table IV shows Positive HC-2/Viral load/ RLU index were found 65 cases, among them more than two third $67.7 \%$ had negative and $21(32.3 \%$ ) had positive. The mean viral load was found $23.0 \pm 82.0$ with range in 0.1 to 461.0 . The threshold of $1 \mathrm{pg}$ of HPV DNA/ $\mathrm{ml}$ of test solution was used for a positive result.

Table-IV

Distribution of the study population by HPV DNA test $(n=65)$

\begin{tabular}{lcc}
\hline HPV DNA test & $\begin{array}{c}\text { Number of } \\
\text { population }\end{array}$ & Percentage \\
\hline$<1$ (Negative) & 44 & 67.7 \\
$\geq 1$ (Positive) & 21 & 32.3 \\
Mean \pm SD & 23.0 & \pm 82.0 \\
Range (min, max) & 0.1 &, 461.0 \\
\hline
\end{tabular}


Table V shows comparison between HC-2/Viral load/ RLU index with age of marriagefinding, it were observed that $13(61.9 \%)$ patients belonged to $\leq 18$ years in $\mathrm{HC}-2 /$ Viral load/ RLU index positive and $27(61.4 \%)$ in HC-2/Viral load/ RLU index negative.

Table-V

Findings of HPV DNA test according to age of marriage $(n=65)$

\begin{tabular}{|c|c|c|c|c|c|}
\hline \multirow{2}{*}{\multicolumn{2}{|c|}{$\begin{array}{l}\text { Age of marriage } \\
\text { (in years) }\end{array}$}} & \multicolumn{4}{|c|}{ Viral load } \\
\hline & & \multicolumn{2}{|c|}{ Positive $(n=21)$} & \multicolumn{2}{|c|}{ Negative $(n=44)$} \\
\hline & $\mathrm{N}$ & $\mathrm{n}$ & $(\%)$ & $\mathrm{n}$ & $(\%)$ \\
\hline$\leq 18$ & 40 & 13 & 61.9 & 27 & 61.4 \\
\hline$>18$ & 25 & 8 & 38.1 & 17 & 38.6 \\
\hline
\end{tabular}

Table VI shows HC-2/Viral load/ RLU index positive were found $8(44.4 \%)$ cases in CIN I, 6(54.5\%) in CIN II and 5(62.5\%) in CIN III evaluated by histopathology.

Table-VI

Relationship between HPV DNA test with histopathological finding $(n=65)$

\begin{tabular}{|c|c|c|c|c|c|}
\hline \multirow{2}{*}{\multicolumn{2}{|c|}{$\begin{array}{l}\text { Histopathological } \\
\text { finding }\end{array}$}} & \multicolumn{4}{|c|}{ HPV DNA test } \\
\hline & & \multicolumn{2}{|c|}{$\begin{array}{l}\text { Positive } \\
(n=21)\end{array}$} & \multicolumn{2}{|c|}{$\begin{array}{c}\text { Negative } \\
(n=44)\end{array}$} \\
\hline & cal & $\bar{n}$ & $\overline{(\%)}$ & $\mathrm{n}$ & $(\%)$ \\
\hline \multicolumn{6}{|l|}{ Negative } \\
\hline $\begin{array}{l}\text { Normal } \\
\text { Positive }\end{array}$ & 28 & 2 & 9.6 & 26 & 100.0 \\
\hline CIN I & 18 & 8 & 38.1 & 10 & 55.5 \\
\hline CIN II & 11 & 6 & 28.6 & 5 & 45.4 \\
\hline CIN III & 8 & 5 & 23.8 & 3 & 37.5 \\
\hline
\end{tabular}

\section{Discussion:}

In this present study it was observed that $35.3 \%$ women belonged to age 21-30 years. The mean age was found $35.5 \pm 9.6$ years with ranged from 21 to 60 years. Nahar et al. $(2014)^{10}$ reported that HPV infection to be most common in younger women with the peak prevalence occurring in women younger than 25 years of age; prevalence started to decline after 30 years of age ${ }^{11}$. The girls of Bangladesh marry at an early age and the study was conducted among married women which may explain high HPV infection in the younger age group. From the present study we get HPV infection $35.3 \%$ in the age $20-30$ years and $32.3 \%$ in age $31-40$ years. In another study Franceschi et al. had showed that age at first marriage and numbers of pregnancies among women were unrelated to HPV positivity ${ }^{12}$. In this study, $66.2 \%$ women had age of marriage $\leq 18$ years \& HPV infection were $61.9 \%$ among them $33.8 \%$ woman had age of marriage $>18$ years \& had HPV infection $38.1 \%$. High parity was also identified as a risk factor for HR-HPV infection ${ }^{12}$. In this series, it was observed that more than three fourth $(73.8 \%)$ patients were multi para ${ }^{13}$. In present study, it was observed that almost two third (66.2\%) patients were asymptomatic and the remains had symptoms likevaginal discharge $20.0 \%$, dyspareunia $9.2 \%$ and post coital bleeding $4.6 \%$. Similar presentations were revealed by Khatun et al. ${ }^{14}$ In the present study, the histopathological finding of the study population were observed that $(43.1 \%)$ population were found normal histopathological followed by $18(42.6 \%)$ were CIN I, 11(26.1\%) were CIN II and 8(19.4\%) were CIN III. Santos et al. $(2003)^{16}$ reported that (19\%) were found to have a normal cervix via colposcopy, (76\%) presented with minor abnormalities and $(4.0 \%)$ with major abnormalities. Of the women with colposcopically guided biopsy (5.0\%) presented with cervicitis in the histological analysis, $66.0 \%$ showed CIN1 and $13(11.0 \%)$ had either CIN2 or CIN3 ${ }^{15}$. In our country Rahman et al. found a distinct upward trend of high-risk HPV DNA viral load, which had correlated with the histologic grade of the lesion, being highest for invasive carcinoma followed by $\mathrm{CIN}$ III, CIN II, CIN I and lowest for chronic cervicitis ${ }^{16}$. Santos et al. mentioned that $85 \%$ of the women with CIN2 or CIN3 had a positive HPV DNA test. In this study $62.5 \%$ HPV infection in CIN III. 54.5\% HPV infection in CIN II, 34.8\% HPV infection present in CIN I \& 8.7\% HPV infection present in normal subjects detected colposcopycally. There were a strong correlation between CIN2 or CIN3 and positivity for HPV DNA when this group was compared with women with only CIN1 or women with normal cervix ${ }^{15}$. In the present study 8 subjects HPV+ve DNA test was $44.4 \%$ found in CIN I, 6(54.5\%) in CIN II and 5(62.5\%) found in CIN III evaluated by histopathology. Sun et al. described women with viral load, were found to be at significantly greater risk squamous intraepithelial lesion. Hubbard had speculated that there may be a relationship 
between high-risk HPV DNA viral load with persistent infection and the subsequent development of preinvasive cervical cancer ${ }^{17}$.

\section{Conclusion:}

From the findings of the study it was observed that colposcopy had a high sensitivity and optimum specificity; HPV DNA test had lower sensitivity and higher specificity. Colposcopic findings were greatly associated with Histopathology, where the validity test was high with compared to HPV DNA test. So it can be concluded that the Colposcopy is a useful screening test for detection of cervical lesions and Human Papillomavirus is associated with preinvasive cervical lessons. So the HPV DNA test can be used as a co-test with Colposcopy for screening of cervical lesions.

\section{References:}

1. Nessa, A., Khatun, S., Chowdhury, T.A., Shamsuddin, L., Islam, M.N., Hassan, M.S, 'Human Papillomavirus in cervical intraepithelial neoplasia in Bangladesh', Bangladesh Journal Obstetrics Gynecology, 2005;20:13-8.

2. Nessa, A., Khatun, S., Huq, F., Islam, M.N., Hasan, M.S., Aziz, M.M. 'Human papillovirus in cervical disease in Bangladesh', Bangladesh Journal of Obstetrics Gynecology, 2006;21: 51-7.

3. Cotton, SC, Sharp, L, Seth, R, Masson, LF, Little, J., Cruickshank, M.E., Neal, K., Waugh, N., TOMBOLA Group, 'Lifestyle and sociodemographic factors associated with high risk. HPV infection in UK women', British Journal of Cancer, 2007;97:133-39.

4. Tobian, A.A., Serwadda, D., Quinn, T.C., Kigozi, G., Gravitt, P.E. 'Male circumcision for the prevention of HSV 2 and HPV infections and syphilis', The New England Journal of Medicine, 2009;360:1298-1309.

5. Marks, M., Gravitt, P.E., Gupta, S.B., Liaw, K.L., Tadesse, A., Colentano, D.D. 'Combined oral contraceptive use increase HPV persistence but not new HPV detection in a cohort of women from Thailand', The Journal of Infectious Diseases. 2011; 204:1505-13.
6. Bahmanyar, E.R., Paavonen, J., Naud, P., Salmeron, J, Chow, SN, Apter, D. 'Prevalence and risk factors for cervical HPV infection and abnormalities in young adult women at enrolment in the multinational PATRICIA study group', Gynecologic Oncology, 2012;127: 440-50.

7. Liao, S.F., Lee, W.C., Chen, H.C., Chuang, L.C., Pan, M.H., Chen C.J. 'Baseline human papillomavirus infection, high vaginal parity, and their interaction on cervical disease risks after a follow up of more than 10 years', Cancer Causes \& Control, 2012;23:703-708.

8. Huq, S.F. 'Common Cancers of Bangladeshthe trends Through Three Decades', British Medical Journal, 1988;63:17-55.

9. Ostor, A.G. 'National institute of cervical intraepithelial neoplasia: a critical review', International Journal of Gynecological Pathology, 1993;12(2):186-92.

10. Nahar, Q., Sultana, F., Alam, A., Islam, J,Y., Rahman, M., Khatun, F., Alam, N., Reichenbach. L. 'Genital Human Papillomavirus Infection among Women in Bangladesh: Findings from Population based survey. PLOS one: 9(10): e107675; 2014.

11. Franceschi, S., Rajkumar, R., Snijders, P.J.F., Arslan, A., Mahe, C., Plummer, M., Sankaranarayanan, R., Cherian, J., C J L M Meijer, C.J.L.M., E Weiderpass, E. 'Papillomavirus infection in rural women in southern India', British Journal of Cancer, 2005; 92:601-06.

12. Franceschi, S., Herrero, R., Clifford, G.M., Snijders, P.J., Arslam, A., Anh, P.T., et. al , IARC HPV prelates servey study group, "Variations in the age-specific curves of human papillomavirus prevalence in women worldwide', International Journal of Cancer, 2006;119:2677-84.

13. Sun, L.L, Jin, Q, Li, H, Zhou, X.R, Song, Z.Q. Population-based study on the prevalence of and risk factors for human papillomavirus infection in qujing of Yunnan province, Southwest China. Virology Journal. 2012;9:153. 
14. Khatun, S., Hussain, S.K., Hossain, F., Choudhury, A. 'Human Papilloma virus and other risk factors of carcinoma cervix', Bangladesh Medical Journal, 2009;38:18-23.

15. Santos, A.L.F., Derchain, M.S.F., Martins, M.R., Sarian, L.O.Z., Martinez, E.Z., Syrjanen, K.J. 'Human papillomavirus viral load in predicting high-grade $\mathrm{CIN}$ in women with cervical smears showing only atypical squamous cells or lowgrade squamous intraepithelial lesion', Sao Paulo Medical Journal, 2003;121:238-3.
16. Rahman, T., Tabassum, S., Jahan, M., Nessa, A. 'Detection and estimation of human papillomavirus viral load in patients with cervical lesions', Bangladesh Medical Research Council Bulletin, 2013;39:86-90.

17. Sun, C.A., Liu, J.F., Wu, D.M., Nieh, S., Yu, C.P., Chu, T.Y. 'Viral load of high-risk human papillomavirus in cervical squamous intraepithelial lesions', International Journal of Gynecology Obstetrics, 2002;76:41-7. 